\title{
鉄道サービスの質的評価に基づいた都市通勤輸送における ハイグレードカーの導入可能性に関する研究
}

\section{AN ECONOMIC EVALUATION OF THE INTRODUCTION OF HIGH-GRADED TRAIN FOR COMMUTER SERVICE IN TOKYO METROPOLITAN REGION}

\author{
肥田野 登*・篠原 穣** \\ By Noboru HIDANO and Yutaka SHINOHARA
}

\begin{abstract}
Large cities face the serious congestion problem of urban mass transportation, e. g. over $250 \%$ in the rush hour. An offer of good service such as the introduction of the train of the good quality is considered as an urgent necessity. Thus the purpose of this paper is threefold ; 1) to estimate the users willingness to pay for high quality services, 2) to find the choice behavior of high-graded train and ordinal train by constructing the discrete choice model based upon the stated preference data and 3) to estimate the social surplus taking account of the cost for the introduction of this new service. The study finds that the introduction of the service with the price of 600 yen per trip generates considerable social benefit.

Keywords : commuter railway service, discrete choice model based upon stated preference data, willingness to pay, cost-benefit analysis
\end{abstract}

\section{1.はじめに}

わが国の大都市における通勤輸送は，高度成長時代以 降，激しい混雑がほとんど改善されないで放置されてき たといっても過言ではない. 中でも東京圏においては, 一点集中型の都市形態と居住地域の拡大のため, 鉄道を 利用して都心へ向かう通勤者の数はきわめて多くなって おり, 朝夕のラッシュ時には各鉄道とも激しい混雑に加 えて, 過密ダイヤのためスピードダウンも強いられてい る.

こうした混雑度の高さや所要時間の増大は, 利用者の 体力の消耗や時間の有効利用の阻害といった点だけみて も社会的に大きな損失になっている．このことは大都市 圈の交通全体から考えてみると, 道路混雑を一層激化さ せている原因の 1 つにもなっているといえよう. 加えて 現在の異常なラッシュは, 社会的弱者の利用をも事実上 拒んでおり, 今後の社会の高㱓化といった背景を考えた とき, 何らかの対策を早急に講ずる必要がある.

このようなラッシュの問題に対する鉄道側の解決策と

* 正会員 工博 東京工業大学助教授 工学部社会工学科 （１52 目黒区大岡山2-12-1）

** 正会員 工修 東日本旅客鉄道株式会社 開発事業本部 ( ₹100 千代田区丸の内 1-6-5)
しては, 複々線化等の輸送力増強工事の完成が挙げられ る. しかし, 全体の混雑率を大幅に下げるための輸送力 増強は, 現行制度のもとでは資金調達を運賃值上げに頼 らざるを得ず, 利用者全体に高運賃を強いることになる。 また地価の高騰をはじめとする種々の事情により, 工事 はなかなかはかよ゙らず, この問題の解決にはきわめて長 い時間が必要である。

一方, 従来の大都市内の鉄道の通勤輸送においては, 列車種別を除いては画一的なサービスが提供されている が, 混雑を我慢しても安く, あるいは早く行きたい人や, 追加料金を支払っても楽に行きたい人など, 利用者の ニーズは多様化の傾向にある. より多くの人のニーズを 満たすことは, 公共交通機関にとって必要なことであり, これからは通勤輸送に対してもサービスの多様化が考え られるべきである.加えてこのサービスの多様化により, 特別なサービスに対する利用者の高い支払意思額を内部 化し，資金調達につなげていくことも可能であり，ラッ シュの問題解決への 1 つの手がかりを提供していると考 えられる。ところが, サービスの多様化に対して実際に ビの程度のニーズがあるか，あるいはそれがどれだけの 実現可能性を有しているかといったことは今までにほと んど明らかにされていない.

そこで本研究では, 鉄道サービスの多様化を図るため 
の方策を考える第一歩として，第 1 に，一般的に最も央 現が難しいと考えられるラッシュ時を取り上げ，交通の 質的サービスに対する評価を行い，第 2 に，ラッシュ時 において必ず座れる定員制の有料の車両をハイグレード カーと名付け，その導入可能性を利用者および事業者の 両方の立場から明らかにすることを目的としている．ま ず 3.では，鉄道サービスの質に対する利用者の支払意 思額を求め，ハイグレードカーに対する意識を明らかに し，4. で利用者のこうしたサービスに対する選択行動 を明らかにする．そして，5. では鉄道利用者全体の余 剩および鉄道事業者の余剩を計測し，実際にハイグレー ドカーの導入が可能か否かについて，西武池袋線の池袋 〜飯能間を対象として，検討することとする.

\section{2. 従来の研究}

このような問題に対する先行研究は, 次の 3 つに分け ることができる．第 1 は交通サービスの質の評価に関す る研究，第 2 は交通サービスの質と需要の関係に関する 研究，第 3 は交通サービスの供給に関する研究である.

第 1 の研究については，まず運輸経済研究センターに よる研究1)が挙げられる。これは意識調査および実験に よって交通の質を構成する項目の定量的な評価を試みて いる．しかし交通サービスの質的側面に関する先駆的な 研究であるため, たとえば混雑度に対してはその限界値 を求めるといった分析にとどまっており，実際に利用者 の立場に立った評価はなされていない，次に利用者の満 足度からアプローチしたものが挙げられる。この種の先 行研究は安山ら ${ }^{2)}$ をはじめ数多く行われている. しかし, これらもいずれも満足度というあいまいな概念の数字で あり, 各研究で調査の対象とした限られた交通サービス の項目間の比較には良いが，絶対的な評価值として扱え ないという問題がある.また, 家田 ${ }^{3)}$, 美谷ら ${ }^{4)}$ は行動デー 夕を用いて着席効用や混雑費用を時間価値により定量化 を試みているが，現状のような激しい混雑のもとでは物 理的限界等から行動を制約されることも多く，また対象 とした項目がきわめて限定されており，乗り換えや待ち 時間などの総合物な質の評価が行われていないという点 にも問題を残している。

第 2 の研究については阿部ら ${ }^{5}$ による研究のほかはほ とんどない，阿部は，ラッシュ時におけるサービスに限 定し，現行車両の座席を有料にして支払意思のある者が 着席できるようなサービスを想定し，そのサービスに対 するコストと利用者の支払意思を意識デー夕から明らか にした。しかし一般車両の全座席に対し料金を課すこと は利用者のコンセンサスを得るのが難しく，また座席ご とにカードリーダーを設置したり，駅ごとに 1 両ずつ客 扱いをする車両を増やす「順次解放方式」をとることは
実現可能性が低い。さらに中間駅での下車を考慮してい ない点に問題を残している.

第 3 の研究については曽根ら ${ }^{61,7)}$ による研究以外はほ とんどなく、これについてもダイヤ改善による輸送力増 強を扱っているだけであり，コスト分析等の経済的視点 からの検討はなされていない.

以上のように，ラッシュ時における鉄道サービスの研 究は, 部分的なものはいくつかみられるが, 利用者の二ー ズを客観的にとらえ，それに応じた施設の整備方策を提 案し，その妥当性を検証するという総合的な研究を行っ たものはないのが現状である.これらに対し本研究では， 利用者のサービスに対する評価值を，意識データを用い てマネータームで表わすと同時に，線増のような大規模 な設備投資を必要としないソフト面の改良により多様な サービスを供給する場合の各主体の余㮃の計測を行うこ とで，こうした問題点を解決することとする。

\section{3. 鉄道サービスの質の評価と利用者の意向}

\section{（1）鉄道サービスの質に対する評価}

まず第 1 の目的に対して，通勤時における鉄道の質に 対する利用者の支払意思額を求めるために，ここでは以 下のように利用者に対して意識調查を行った．評価を行 う項目は，鉄道サービスの中でも鉄道事業者による整備 効果という点から考えて最も代表的と思われる乗り換 え・冷房・着席・エスカレーター・混雑度・待ち時間の 6 項目とした。

調査の方法としては，行動分析では質を構成する各種 の項目の効果の大きさを判断するのに十分なデー夕を入 手することが困難なため意識分析によることとし，また 意識調査は実際のケースではなく仮想の状況によること とした。これは，実際のケースでは調査結果が鉄道サー ビスの項目以外の影響も受けることを考虑したためであ る。なお設定した状況は，東京近郊で多く想定され得る ものとした，さらに通勤者を対象としているので，基準 となる運貨は雇用者側が支払うものとし，個人はその増 分だけを支払うものとしている.

質問形式は, 各サービス項目の効用を明確化するため, 1 項目ごとにサービス水準の異なる 2 つの経路を示し， 他の項目は同条件とした状況を設定し，サービス水準の 高い経路をとる限度となる運賃を選択肢により回答して もらう方式とした．調查表の例は図一1，また調査の概 要は表一1のとおりである。

支払意思額の推定にあたっては，サービス 1 項目と運 貨で構成される線形の効用関数を設定し，次の式による 非集計ロジットモデルを用いて最尤推定によりパラメー ターを推定した。 


$$
P_{i n}=\frac{e^{v_{i n}}}{e^{V_{1} n}+e^{v_{2 n}}}
$$

その確定項は次の式で表わされる.

$V_{i n}=\theta_{1} X_{i 1}+\theta_{2} X_{i 2}$

ここに, $\theta:$ パラメーター, $X_{i 1}: i$ 経路の運賃 (円),

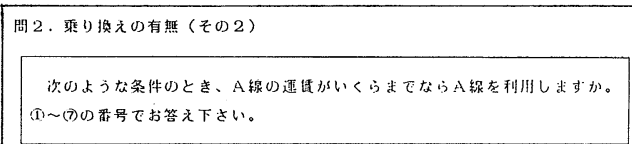

・混みぐあいは、どちらもちょうど全员がつり皮につかま机る程展

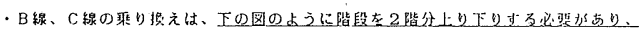

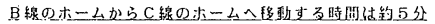

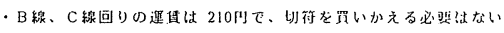

.八駅て C 媲在待つ時用は 5 分
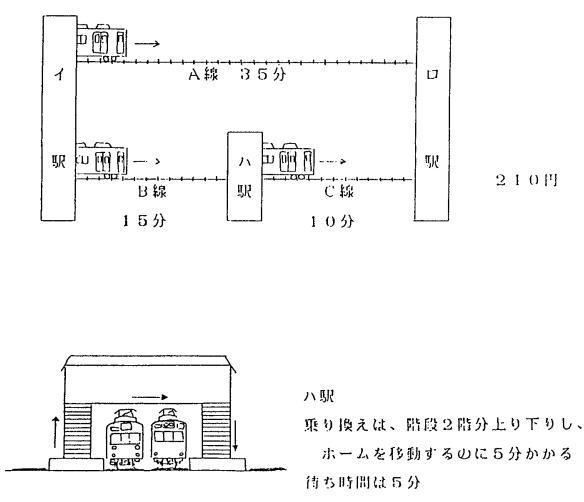

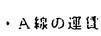

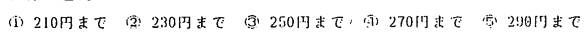
(i) 310 r

国筑 ( )

図一1＼cjkstart鉄道の質に関する調査表（例）

\section{表一1 調査の概要}

\begin{tabular}{|c|c|}
\hline 対象地域 & 山手線沿線及びその内側（事業所） \\
\hline 対象者 & $\begin{array}{l}\text { 対象地域に位置する事業所の } \\
\text { 電車通勤者 }\end{array}$ \\
\hline 調查日 & $\begin{array}{l}1986 \text { 年 } \\
1 \text { 月 } 13 \text { 日 } 1 \text { 月 } 27 \text { 日 }\end{array}$ \\
\hline 調查方法 & 事業所単位の訪問留珇または郵送 \\
\hline 配布数 & 148 \\
\hline 有効回収数 & 137 \\
\hline 有効回収率 & $92.6 \%$ \\
\hline
\end{tabular}

$X_{i 2}: i$ 経路のサービス (ただしサービスは $1-0$ 変数).

このとき, 効用の全微分は

$d V=\frac{\partial V}{\partial X_{1}} d X_{1}+\frac{\partial V}{\partial X_{2}} d X_{2}$

と表わされる.サービスに対する評価額を求めることは, サービスの微小変化に対する運賃の微小変化の割合を求 めることであるから，総効用は変化しないとして両者の 関係を求めればよいことになる.すると， $d V=0$ より

$$
\frac{d X_{1}}{d X_{2}}=-\frac{\partial V / \partial X_{2}}{\partial V / \partial X_{1}}
$$

なお分析にあたっては, 意識調査の回答值を両方の経 路の運顀とサービスの均衡点と考え, 基準值 (210 円) と（意識調査の平均 $+2 \sigma$ ) の間にサンプルが存在する と仮定し，この区間に比較する経路の運賃を一様分布で 発生させこの值と回答值から選択結果を得て先に示した 非集計ロジットモデルでパラメーターの推定を行った。 この結果は, 表一2に示すとおりである.

「乗り換え」・「混雑度の違い」・「待ち時間の長さ」に 関しては適当に条件を与えたため, 単純に項目間で比較 することはできないが，この条件のもとでの支払意思額 の違いについて考察を行う.

同一ホームでの乗り換えは, 乗り換えの中では最も便 利なケースだが，それでも乗り換えのない方が 40 円弱 も評価されていることから，この金額が乗り換えという 行動自体に対する最低額と考えられる.これに対して, 乗り換えの際に階段 2 階分の上り下りを必要とする場合 は，同一ホームのときと比較して 10 円弱高くなってお り，乗り換えの際階段 2 階分の抵抗は 10 円弱であると 考えられる.

「冷房の有無」は50円前後,「着席の可否」と, 混雑 度を 150 \% と $250 \%$ に設定した「混雑度の違い」に対 しては，いずれも 40〜 50 円の評価が得られている．運 賃水準に比べると比較的高い值となっており，こうした サービスに対する支払意思をもったニーズはかなり高い ものと考えられる.

\section{（2）ハイグレードカーに対する利用者の意識}

ハイグレードカーに類するサービスは近年注目されつ つあり, JR のホームライナー等しだいに増えつつある

\begin{tabular}{|c|c|c|c|c|c|c|c|c|}
\hline & $\begin{array}{l}\text { 同一ホー倠え } \\
\text { (有り、無し) }\end{array}$ & $\begin{array}{l}\text { 階段2階分 } \\
\text { 符有り、無し) }\end{array}$ & $\begin{array}{c}\text { 冾 房 } \\
\text { (有り、無し) }\end{array}$ & $\begin{array}{c}\text { 着 } \\
\text { (有り、無し) }\end{array}$ & $\begin{array}{c}\text { エススカ } \\
\text { 有り、無し) }\end{array}$ & $\begin{array}{c}\text { 混雓度 } \\
(250 \%, 150 x)\end{array}$ & $\begin{array}{l}\text { 最大待方時間 } \\
\text { (8分, 4分) }\end{array}$ \\
\hline \multirow{2}{*}{ 説 } & $\begin{array}{c}\text { サービス } \\
(\text { 七値) }\end{array}$ & $\begin{array}{r}-0,0816 \\
(-5,1) \\
\end{array}$ & $\begin{array}{r}-0.0708 \\
(-5.6)\end{array}$ & $\begin{array}{r}-0,0535 \\
(-4,7)\end{array}$ & $\begin{array}{r}-0,0660 \\
(-5,2)\end{array}$ & $\begin{array}{r}-0,163 \\
(-5,3) \\
\end{array}$ & $\begin{array}{r}-0,0571 \\
(-5.2) \\
\end{array}$ & $\begin{array}{r}-0,0909 \\
(-5,6) \\
\end{array}$ \\
\hline & (運唲) & $\begin{array}{l}3.07 \\
(6.6)\end{array}$ & $\begin{array}{r}3.27 \\
(8.4)\end{array}$ & $\begin{array}{r}2.77 \\
(5,1) \\
\end{array}$ & $\begin{array}{r}2.82 \\
(5,3)\end{array}$ & $\begin{array}{r}4.58 \\
(5.9) \\
\end{array}$ & $\begin{array}{r}2.52 \\
(5.3) \\
\end{array}$ & $\begin{array}{r}3.58 \\
(6.1)\end{array}$ \\
\hline \multirow{2}{*}{\multicolumn{2}{|c|}{$\begin{array}{c}\text { 尤度比 } \\
\text { サンブル数 }\end{array}$}} & 0.38 & 0.40 & 0.20 & 0.30 & 0.59 & 0.25 & 0.43 \\
\hline & & 137 & 136 & 123 & 123 & 136 & 128 & 132 \\
\hline \multirow{2}{*}{\multicolumn{2}{|c|}{$\begin{array}{l}\text { 支払意思額 } \\
\text { 適中率 }\end{array}$}} & $37.7 \mathrm{p}$ & $46.1 \mathrm{H}$ & $51.7 \mathrm{~m}$ & 42.8 円 & $28.0 \mathrm{P}$ & $44.1 \mathrm{H}$ & $39.4 \mathrm{P}$ \\
\hline & & $83.2 \%$ & $83.8 \%$ & $75.0 \%$ & $71.5 \%$ & $90.4 \%$ & $73.4 \%$ & $81.8 \%$ \\
\hline
\end{tabular}

表一2 ロジットモデルによる分析結果 


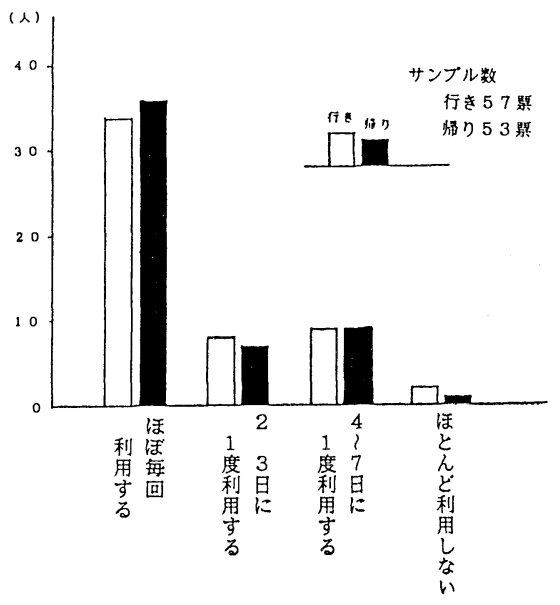

図一2 レッドアロー号の利用頻度

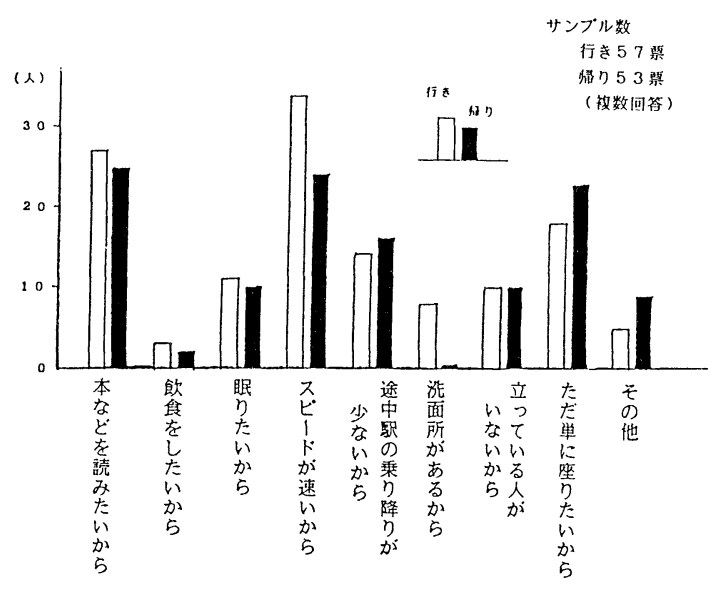

図一3 レッドアロー号を利用する理由

が，その実数はまだあまり多くない，また，実際に導入 されているところでも，観光特急の片手間といった感じ のものが多く，通勤輸送を主目的としたものはない。そ こで，ハイグレードカーに対する見解を，利用者，鉄道 事業者および監督官庁に分けて明らかにした。

まず利用者の実態と考え方を明らかにするため，本研 究においてハイグレードカーとよべるサービスを提供し ている西武池袋線の特急レッドアロー号の車内において 意識調査を実施した。調査は車内に調査員が乗り込み, 列車発車時に調查用紙を配布し，到着前に回収する方法 で行った，その概要を表一3に，また集計結果を図一2, 図一 3 に示す。これより, 利用者は全般的に利用頻度が かなり高いこと，また利用する理由では「スピードの速 さ」,「読書等ができる」といった，時間の有効利用に関 するものを挙げている割合が高いことがわかった。さら に, 自由回答では特急の座席数や列車数の増加を望む声
表一3 調査の概要

\begin{tabular}{|c|c|c|}
\hline 調查日 & \multicolumn{2}{|c|}{1987 年 11 月17日(火) } \\
\hline 調査列車 & むさし 6 号 & むさし 27 号 \\
\hline 調査区間 & 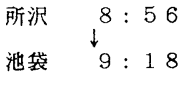 & $\begin{array}{l}\text { 池袋 } 18: 08 \\
\downarrow \\
\text { 所沢 } 18: 31 \\
\text { (饭能行 } 18: 48 \text { 着) }\end{array}$ \\
\hline 調查車両 & 1 号車 & 6 号車 \\
\hline サンプル数 & 57 票 & 53 票 \\
\hline
\end{tabular}

表一4 ハイグレードカーに対する鉄道事業者および監督官庁の 見解

\begin{tabular}{|c|c|}
\hline 鉄道事業者 & 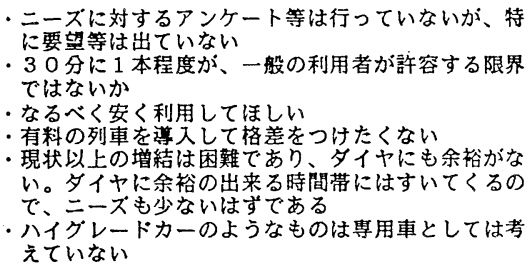 \\
\hline 運输省 & 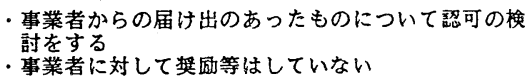 \\
\hline
\end{tabular}

が多かった．これとは別に，レッドアロー号や小田急の 特急, JR の各ホームライナーの切符の発売状況を観察 したが，発車時間の 20 分以上も前に売り切れになった り，キャンセル待ちで並ぶ人が大勢いることなどがわ かった．以上の点から，こうしたサービスに対する潜在 需要はかなりあることが推察された。

一方，関東の大手私鉄および監督官庁である運輸省に 対してヒアリングを行った結果を表一 4 にまとめて示 す．運輸省としては全体の混雑度を下げる方針で考えて いるため，また鉄道事業者としては利用者の二ーズが明 らかでないことから，いずれもハイグレードカーの導入 に対しては消極的になっていることがわかったままた， 鉄道事業法第 16 条には，料金認可の際の基準として適 正利潤を含むものであり，特定の旅客に不当な差別的取 扱いをするものでないことと定められている。したがっ て事業者がサービスの多様化に対して工夫をこらして も，適正利潤以上の利潤を認められないことや，「不当 な差別的扱い」をめぐる解釈の問題があるため, 事業者 のインセンティブが働きにくくなっているといったこと も考えられる.

以上から，八イグレードカーに対する利用者のニーズ の高さを考えれば，鉄道事業者や監督官庁の見解をふま えながらも，その導入に対して積極的な方策を検討して いくことは，社会的に必要であると考えられる.

\section{4. ハイグレードカーの選択行動の推定}

日常の利用者がハイグレードカーを選択する行動を推 
定するため, 本研究では定期券利用者を対象として意識 調査を行った，意識デー夕を用いる理由としては，対象 線区では多くの列車が満員になっており, 行動デー夕が 必ずしもニーズを反映していないのに対し，意識データ は潜在需要を含めた全体のニーズを明らかにすることが 挙げられる，さらに，意識デー夕は条件をさまざまに変 化させることにより，より多くのケースの推定が行える といった利点も挙げられる.

\section{(1) 調査の概要}

調査の概要は, 表一5 のとおりである. 調査は熟練し た調査員による面接方式で行い，朝の上りと夕方の下り

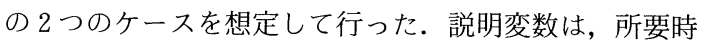
間，運転間隔，料金とし，OD に応じてそれぞれ $2 \sim 4$ 通りの条件を用意した．通常は，これらすべての条件を 組み合わせて調査を行うこととなるが，その数は 32 通 りになり,これを調査することは被験者に調査疲れを起 こすおそれがある.そこで今回は実験計画法による $\mathrm{L}_{8}$ の割り付け表を利用し，八イグレードカーに関する条件 の組合せを 8 通りに絞ったうえ, これらと一般車の現状 の条件との間で一対比較をし，八イグレードカーを利用 する頻度を答えてもらう方式とした。

\section{(2) 分析方法}

分析にあたっては次の式で表わされる非集計ロジット モデルを用いることとし，効用関数の説明変数にはさき に述ベた 3 項目にハイグレードカーのダミ一変数と, 個 人属性として年齢および年収を加え，これらを組み合わ せて分析を行った。

$$
P_{1 n}=\frac{e^{V_{1} n}}{e^{V_{1} n}+e^{V_{2 n}}}
$$

\section{表一5 調査の概要}

\begin{tabular}{|c|c|}
\hline 調査日 & $\begin{array}{r}1987 \text { 年 } 11 \text { 月 } 27 \text { 昌 (金) } \\
12 \text { 月 } 1 \text { 夏) }\end{array}$ \\
\hline 調查時間 & $16: 30 \sim 20: 30$ \\
\hline 調査場所 & 西武池袋駅地下定期券発売所前 \\
\hline 調查対象 & 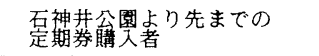 \\
\hline 回収数 & 309 票 \\
\hline
\end{tabular}

表一 6 パラメーター推定結果 (ケース 1 )

\begin{tabular}{|c|c|c|c|c|}
\hline & \multicolumn{2}{|c|}{ 朝 $($ 上り) } & \multicolumn{2}{|c|}{ 多方 (下只) } \\
\hline & パラメーター & 料金代替車 & パラメーター & 料金代替率 \\
\hline 所要時間 （分） & $\begin{array}{l}-0.038 \\
(-3.21)\end{array}$ & -1.81 & $\begin{array}{l}-0.040 \\
(-3.62)\end{array}$ & -2.00 \\
\hline 運転間隔 & $\begin{array}{l}-0.042 \\
(-3.81)\end{array}$ & -2.00 & $\begin{array}{l}-0.049 \\
(-5.95)\end{array}$ & -2.45 \\
\hline 料金 & $\begin{array}{l}-0.021 \\
(-11.0)\end{array}$ & & $\begin{array}{l}-0.020 \\
(-11.4)\end{array}$ & \\
\hline 年酸 (10歲) & $\begin{array}{r}-0.28 \\
(-4.85)\end{array}$ & -13.3 & $\begin{array}{l}-0.24 \\
(-4.41)\end{array}$ & -12.0 \\
\hline ハイグレードー & $\begin{array}{l}0.92 \\
(2.67) \\
\end{array}$ & 43.8 & $\begin{array}{l}1.10 \\
(3.87)\end{array}$ & 55.0 \\
\hline 尤度比 & & & & \\
\hline 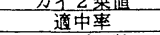 & & & & \\
\hline サンプル数 & 309 & & 309 & \\
\hline
\end{tabular}

効用関数の確定項は次の式で表わされるものとする.

$$
\begin{aligned}
& V_{1}=\theta_{1} T_{1}+\theta_{2} t_{1}+\theta_{3} F+\theta X+\theta_{4} D \\
& V_{2}=\theta_{1} T_{2}+\theta_{2} t_{2}
\end{aligned}
$$

ここに, $T:$ 列車 $i$ の所要時間

\section{$t:$ 列車 $i$ の運転間隔}

$F ：$ ハイグレードカーの料金

$D ：$ ハイグレードカーダミー

$\boldsymbol{X}:$ 個人属性のベクトル

$\theta_{1} \sim \theta_{4}, \boldsymbol{\theta}:$ パラメーター

\section{(3) 推定結果および考察}

$t$ 值および尤度比を検討し，有効と思われるケースの パラメーターの推定結果は表一 6 から表一 9 のように なった。なお，料金代替率とは，ある変数の 1 単位をマ ネータームに換算したもので，これがそのサービス 1 単 位に対する利用者の支払意思額になる．たとえば表一 9 における夕方のハイグレードカーダミー変数の 158 之

\begin{tabular}{|c|c|c|c|c|}
\hline & \multicolumn{2}{|c|}{ 朝(上り) } & \multicolumn{2}{|c|}{ 夕方(下う) } \\
\hline & パラメーター & 料金代替実 & パラメーター & 料金代替率 \\
\hline 所要時間 (分) & $\begin{array}{l}-0.041 \\
(-3.13)\end{array}$ & -5.32 & $\begin{array}{l}-0.038 \\
(-3.16)\end{array}$ & -5.00 \\
\hline 運転間陽 （分） & $\begin{array}{l}-0.042 \\
(-3.48)\end{array}$ & -5.45 & $\begin{array}{l}-0.061 \\
(-6.78)\end{array}$ & -8.03 \\
\hline 料金 & $\begin{array}{l}-0.0077 \\
(-12.6)\end{array}$ & & $\begin{array}{l}-0.0076 \\
(-13.1)\end{array}$ & \\
\hline 年収 $(100$ 万円) & $\begin{array}{r}0.097 \\
(3.32) \\
\end{array}$ & 12.6 & $\begin{array}{r}0.098 \\
(3.41) \\
\end{array}$ & 12.9 \\
\hline $\begin{array}{r}\text { ハイグレードカー } \\
\text { (タミー) }\end{array}$ & $\begin{array}{c}0.24 \\
(0.79)\end{array}$ & 31.2 & $\begin{array}{c}0.68 \\
(2.66)\end{array}$ & 89.5 \\
\hline 尤度比 & 0. & & 0.2 & \\
\hline カイ2垂值 & & & 375 & \\
\hline 道中率 & 87 & & 87 & \\
\hline サンプル数 & 309 & & 309 & \\
\hline
\end{tabular}
は，ハイグレードカーサービス自体に対し平均して約

表一7 パラメーター推定結果（ケース 2 ）

\begin{tabular}{|c|c|c|c|c|}
\hline & \multicolumn{2}{|c|}{ 朝(上只) } & \multicolumn{2}{|c|}{ 夕方 (下り) } \\
\hline & パラメーター & 料金代替率 & パラメーター & 料金代替率 \\
\hline 所要時間 (分) & $\begin{array}{r}-0.036 \\
(-2.93) \\
\end{array}$ & -1.71 & $\begin{array}{r}-0.042 \\
(-3.76) \\
\end{array}$ & -2.10 \\
\hline 運転間隔 & $\begin{array}{l}-0.044 \\
(-3.84)\end{array}$ & -2.10 & $\begin{array}{l}-0.051 \\
(-6.07)\end{array}$ & -2.55 \\
\hline $\begin{array}{l}\text { 料金/年取 } \\
\text { (円/ } 100 \text { 万) }\end{array}$ & $\begin{array}{r}-0.021 \\
(-10.8) \\
\end{array}$ & & $\begin{array}{r}-0.020 \\
(-11.1) \\
\end{array}$ & \\
\hline 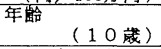 & $\begin{array}{c}-0.28 \\
(-4.78)\end{array}$ & -13.3 & $\begin{array}{l}-0.27 \\
(-4.62)\end{array}$ & -13.5 \\
\hline $\begin{array}{r}\text { ハイグレードカー } \\
(\text { (タミー) }\end{array}$ & $\begin{array}{c}0.94 \\
(2.64)\end{array}$ & 44.8 & $\begin{array}{c}1.12 \\
(3.79)\end{array}$ & 56.0 \\
\hline 尤度比 & \multicolumn{2}{|c|}{0.14} & \multicolumn{2}{|c|}{0.15} \\
\hline 力イ2乗值 & \multirow{2}{*}{\multicolumn{2}{|c|}{$\begin{array}{l}235.6 \\
87.6\end{array}$}} & \multirow{2}{*}{\multicolumn{2}{|c|}{$\frac{272.3}{56.7}$}} \\
\hline 適中率 & & & & \\
\hline サンブル数 & \multicolumn{2}{|c|}{309} & \multicolumn{2}{|c|}{309} \\
\hline
\end{tabular}

表--8 パラメーター推定結果（ケース 3 )

\begin{tabular}{|c|c|c|c|c|}
\hline & \multicolumn{2}{|c|}{ 朝（上り） } & \multicolumn{2}{|c|}{ 多方（下り） } \\
\hline & パラメーター & 料金代替事 & パラメーター & 料金代替事 \\
\hline 所要時間 （分） & $\begin{array}{l}-0.045 \\
(-3.43)\end{array}$ & -5.8 & $\begin{array}{l}-0.035 \\
(-2.96)\end{array}$ & -4.6 \\
\hline 運転間隔 （分） & $\begin{array}{l}-0.042 \\
(-3.44)\end{array}$ & -5.5 & $\begin{array}{l}-0.064 \\
(-7.10)\end{array}$ & -8.4 \\
\hline 料金 & $\begin{array}{l}-0.0077 \\
(-12.5)\end{array}$ & & $\begin{array}{l}-0.0076 \\
(-13.1)\end{array}$ & \\
\hline $\begin{array}{r}\text { ハイグレードカー } \\
(\text { タミー) }\end{array}$ & $\begin{array}{c}0.67 \\
(2.43)\end{array}$ & 87.0 & $\begin{array}{l}1.2 \\
(5.71)\end{array}$ & 158 \\
\hline 尤度比 & 0.1 & & 0.2 & \\
\hline カイ 2 㐘値 & 329 & & 322 & \\
\hline 適中率 & 87. & & 86. & \\
\hline サンブル数 & 309 & & 309 & \\
\hline
\end{tabular}

表一9 パラメーター推定結果（ケース4) 
160 円の価值を利用者が認めているということになる. 結果については, $t$ 值, 尤度比, カイ二乗値とも比較的 高い值が得られており，かなり信頼できる結果が得られ ている.

全体的な傾向として, 所要時間, 運転間隔, 料金につ いては往復とも比較的近い数值が得られているが，八イ グレードカーダミーの項については他の項目に比べて著 しく高い数值が得られており，この項目に対する評価は かなり高いことがわかる．また，同じ八イグレードカー ダミーの項でも夕方の下りの值がかなり高くなってい る.これは，朝の上りよりも夕方の下りの方がゆったり としたサービスに対する評価が高いことのほか，帰りは 全員が始発列車を利用することになるため，一般の車両 に比べて質的な面の評価のウエイトが高くなっているも のと考えられる. また，料金の $t$ 值がかなり大きくなっ ており, 料金の項目が効いていることがわかる. そして, 運貨水準に比ベハイグレードカーダミ一変数の料金代替 率が高いことから，この効用関数においては料金の弾力 性がかなり高いといえる。ささら，表一7に現われてい るように，年収に関しても $t$ 值は十分な值を得ており， ハイグレードカーのようなサービスを望んでいる人の中 でも年収の高い人のニーズがとりわけ大きいことが読み 取れる.

\section{5. 導入可能性の検討}

\section{（1）導入可能性の検討方針と対象の選定}

本研究ではハイグレードカーの導入可能性を利用者お よび事業者の両方の立場から明らかにすることを目的と している. その際の考え方は以下のとおりである. 利用 者に関しては, 利用者全体の余剩が増加することが必要 である，ただし，余剩が負になるような利用者が生じる ことは好ましくないので各利用者のサービスレベルは少 なくとも現行の水準から低下しないようにすることが大 切である. 事業者に関しては, 新サービスの導入により コストは増加するが，それにより経営が圧迫されないよ う，料金収入が少なくともコストをまかなえることが必 要である. そして, 利用者と事業者の余剩の和を社会総 余剩とし，この大きさについても検討することとする.

またここでは対象をラッシュ時に限定しているが, 朝 と夕方ではその性格を異にしている. 夕方はピーク集中 率はやや低く,幅広い時間帯に利用者が分散しているが, 朝は比較的短い時間帯に利用者が集中しているので混雑 も激しくなっており，社会的弱者などの存在を考えると 公共交通機関としては朝の方がハイグレードカーのよう なサービスの必要性が高く，かつ実現が難しいと考えら れる. したがってここでは, 西武池袋線を対象として朝 のラッシュ時における導入可能性を検討することとす
る.

\section{（2）導入条件の検討}

導入にあたっては次の条件を満たすこととした。

(1) 現行のサービスレベルは極力低下させない

(2) 線増や信号改良といった，大規模なシステムの変 更は行わない

新たなサービスを導入する場合でも，現行のサービス レベルを低下させてしまうと当該利用者のコンセンサス を得にくくなることは明らかである．特にこうしたサー ビスについては特別料金を必要とする列車への置き換え とするのではなく，選択の幅を広げることが目的である ので，(1)のような条件を設けた，サービスレベルをみる 項目としては平均総所要時間および混雑度を取り上げ た. 平均総所要時間は以下の式で表わされるものとする.

$$
A T=\sum_{i=1}^{L} P_{i}\left(T_{i}+I_{i}\right)
$$

ここに, $L$ : 当該 OD で選択可能な列車（ハイグレー ドカーと一般車を分離する) の本数

\section{$P_{i}: i$ 列車の選択確率}

$T_{i}: i$ 列車の所要時間

$I_{i}: i$ 列車の平均待ち時間

なお，全員に対してサービスレベルを低下させないこ とは難しいので, もし低下が生じた場合には負の効果と して計測することとした．また(2)については，これらの

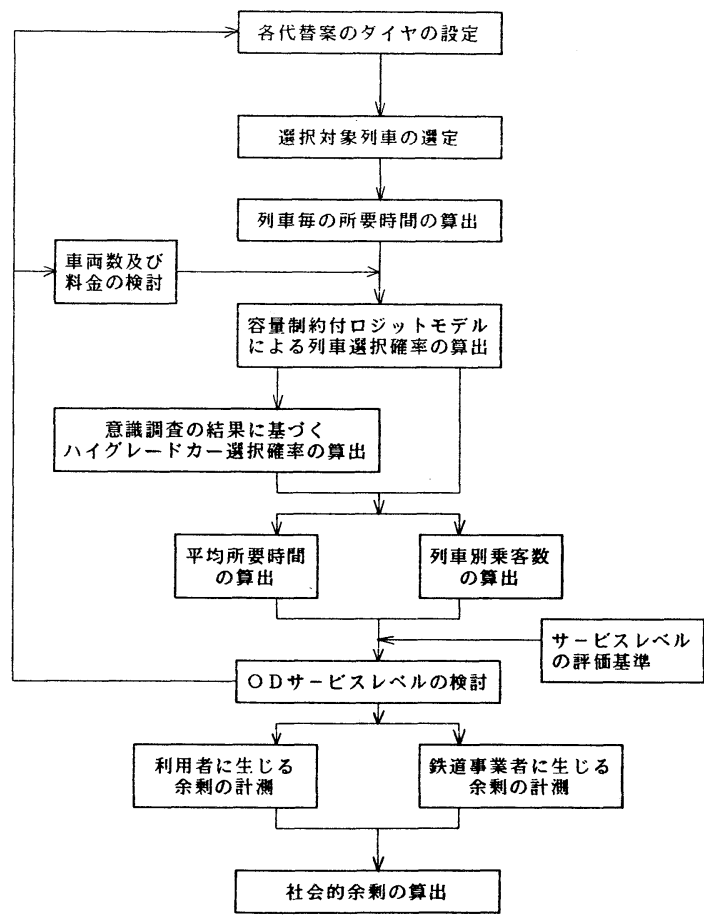

図一4導入可能性の検討のフロー 
設備の変更には多額の資金と長い時間を必要とするた め, 実際の導入が容易に行えるように設けたものである.

\section{（3）導入可能性の検討方法}

さきに述べたように本研究では利用者と事業者の両方 の立場をふまえたうえで社会的余㮃を計測し，八イグ レードカーの導入可能性について検討を行うこととして いる，そこで，検討のフローを図一4のようにした。

上に述べた条件を満たすために，代替案では輸送力増 強型のダイヤを設定し，そのダイヤに基づいて OD ご とに利用の対象となり得る列車および乗継ぎのパターン を抽出し，その所要時間および乗り換えの待ち時間を求 める。ここで，ハイグレードカーの車両数や料金を検討 し，容量制約付きのロジットモデルによって列車選択確 率を求める. さらに，八イグレードカーの選択可能な OD に関しては，先の意識調査で得られたパラメーター を用いて，八イグレードカーの選択確率を求める。 そし てそれらから平均所要時間および列車別の乗客数を求め る.これらを用いて, OD サービスレベルの検討を行い, サービスレベルが著しく低下した場合は再度ダイヤを検 討する．また，サービスレベルが上がっている場合には 利用者と鉄道事業者の余剩の計測を行うこととした.

\section{（4）輸送力增強型ダイヤの検討}

八イグレードカーはラッシュ時の一般車に比べて 1 両 当たりに乗車できる人数は 5 分の 1 以下であり, 一般車 の利用者のサービスレベルを低下させることなくハイグ

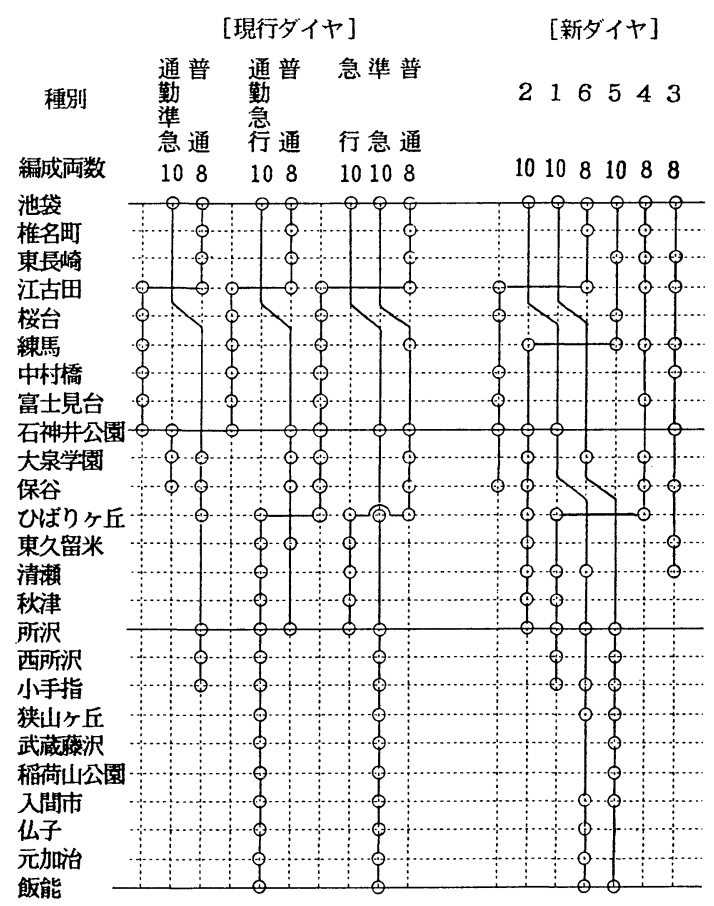

図一－新ダイヤと現行ダイヤの停車駅比較
レードカーを導入するためには輸送力の増強は不可欠で ある。ところが，今の輸送形態では輸送力はほぼ限界と なっており，これ以上の増強は難しい，そこで，ここで はラッシュ時, 上り列車のみ, 列車の停車パターンの大 幅な変更を行うことにより, 輸送力を増強することを考 えた。

一般に列車密度は, 停車駅に影響されることがわかっ ている. 同じ駅に停車する列車が続くと運転間隔は開か ざるを得ない．また待避駅が少ないと優等列車（急行な ぞ）は各駅停車のため速度が低下する，そこで今回取り 上げたのは, 各駅停車をなくしスピードの遅い優等列車 と合わせて，2〜3 駅ごとに停車する列車の組合せに再 編成するものである.これに, 余裕時分の切り詰めによ る車頭間隔の短縮を合わせることで, 輸送力増強型のダ イヤを作成した，停車パターンを図一5に，また，それ に基づくダイヤを図一6に挙げた. 現行の 15 分サイク ルのパターンダイヤを 12 分パターンダイヤに変えるこ とにより, 池袋口において 1 時間当たり 14 両分の輸送 力の増強が可能になった。なお，八イグレードカーは, 停車パターンと考え合わせた結果, 図一 5 の $1,2,5$ の

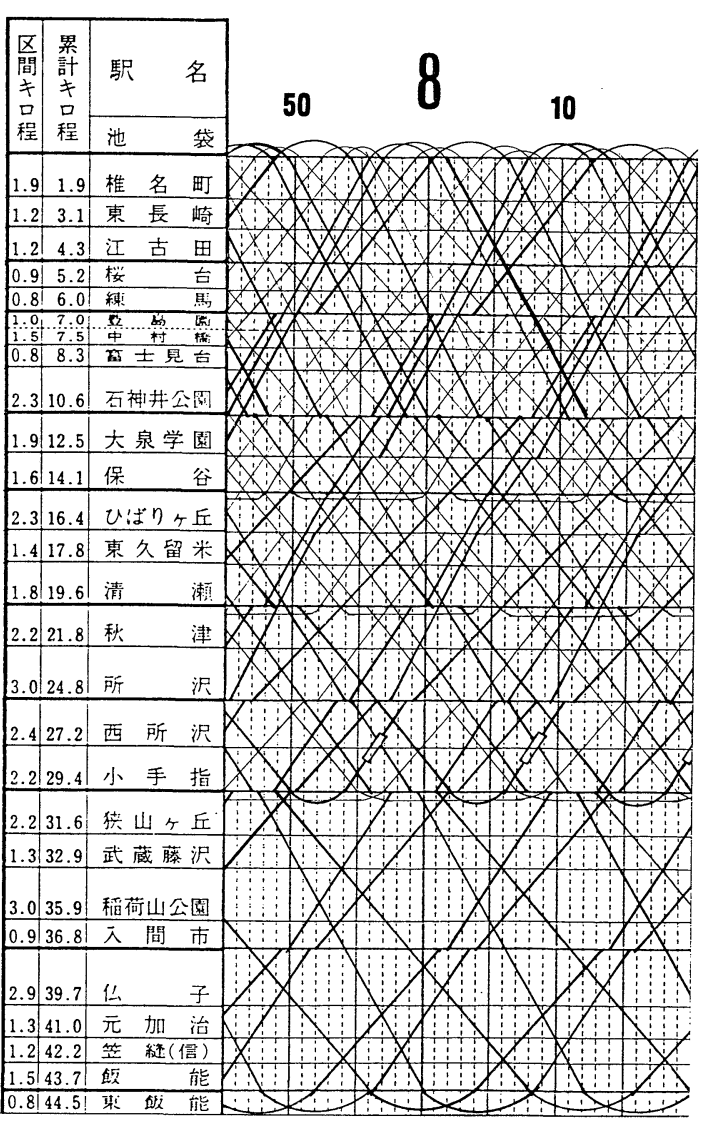

図一6 新ダイヤ（横軸 1 目盛は 1 分） 
列車に連結することとした（図一6では太線で示す）.

\section{（5）列車選択行動の推定}

輸送計画をたてるうえでは, どの列車にどのくらいの 利用者がいるかを知ることが必要である。ここでは利用 者は, 列車を選択する際に個人の効用が最も高くなるよ うな列車を選ぶものと考え, 列車選択行動を推定する.

本研究では，八イグレードカ一の利用者を含めた全体 の選択行動を図一7 のような構造とした。一般車しか利 用できない OD については, 一般車における列車間の 選択のみが行われるものとした．列車間の選択に関して は，まず OD ごとに利用者が利用の対象とすると考え られる列車をいくつか選定し，そのおのおのについて乗 車時間，乗り換え時間，乗り換え待ち時間を求めた．そ してそれらを説明変数とし，大都市交通センサスの集計 データから集計ロジットモデルにより求められるパラ メーター8) (表一10) を利用して, また八イグレードカー と一般車の選択については前述した調査から求めたパラ メーターを用いておのおのロジットモデルにより選択確 率を求めた。ただし，利用者全体の年秢・所得分布が明 らかでなくまた適中率・尤度比がモデルによって大きな 差がないので，集計時におけるバイアスを防ぐため，こ こでは変数から年齿・所得といった個人属性を除いた表
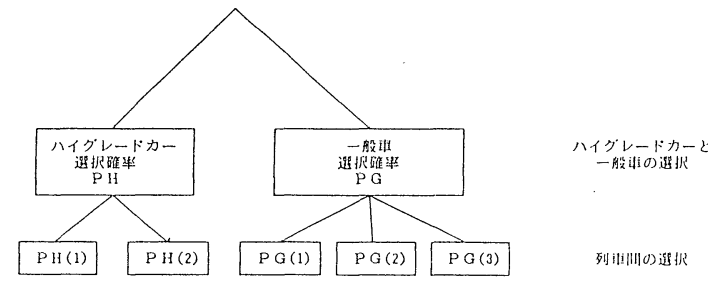

図一7 列車選択の構造

表一10 推定モデルで用いたパラメーター

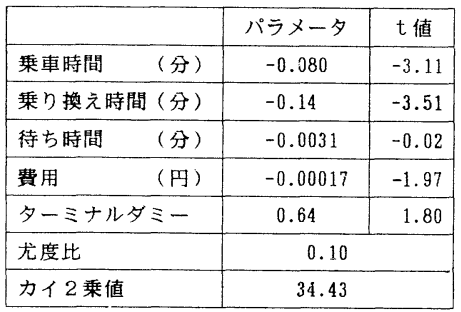

（昭和 60 年大都市交通センサスによる）

表一11 列車選択モデルの推定結果と実態の比較

\begin{tabular}{|c|c|c|c|c|c|c|c|}
\hline 列車種别 & 通勤急行 & 通 & 急行 & 草 急 & 普 通 & 通勤唖急 & 音 \\
\hline a 推定值 & 80 & 2610 & 4220 & 3800 & 2530 & 4010 & 2680 \\
\hline b 実績值 & 3750 & 2180 & 4210 & 4380 & 2810 & 4010 & 2710 \\
\hline$a / b(\%)$ & 03 & 120 & 100 & 87 & 90 & 100 & 99 \\
\hline
\end{tabular}

一9のパラメーターを用いた.

このモデル全体の妥当性を検証するために，現行ダイ ヤでの池袋口における実際のピーク時 1 サイクルの乗車 人員と推定結果を示したものが表一11である。なお， 今回の効用関数には混雑度が入れていないが, 特定の列 車に容量を越えて集中することもあるため，一般車につ いては容量制約付きのモデル $\left(P_{i}=M_{i} \exp \left(V_{i}\right) / \sum M_{j}\right.$ $\exp \left(V_{j}\right), M_{i}$ は容量 $)$ とすることで混雑度を入れる代 わりとした．この表から，このモデルはかなりよく適合 しているといえる，そこで，新ダイヤによる説明変数を 用いて，各列車ご之の利用者数を求めた。ただし，八イ グレードカーに関しては，都心から遠いところから乗る 人や早く切符を買った人が優先されるのではなく，ある 条件で利用したい人は全員が利用できることが望ましい と考え, 需要が増強された輸送力に合うように料金を変 化させたところ，600 円のときに需要と供給のバランス がとれることがわかったそそこで以下では，料金を 600

\section{表一12 代替案一覧表}

\begin{tabular}{|c|c|c|c|}
\hline & \multicolumn{3}{|c|}{$\tau-z$} \\
\hline & (1) 現行 & 六ィ新名イ吉カー無し & 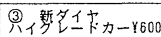 \\
\hline トレインアワー & 29 時閪 31 分 & 34 時間 23 分 & 34 時間 23 分 \\
\hline カーアクー & 276 時阔 45 分 & 316 時间 0 分 & 316 時間 0 分 \\
\hline 最大使用本数 & 41 本 & 44 本 & 44 本 \\
\hline 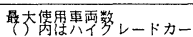 & $\begin{array}{l}378 \text { 耐 } \\
(0 \text { 禹 }\end{array}$ & 48 峏 & $(250$ 㟀禹 \\
\hline
\end{tabular}

表一13 各駅間ごとの平均混雑度

\begin{tabular}{|c|c|c|c|}
\hline \multirow{2}{*}{ 名 } & \multicolumn{3}{|c|}{ 平均 混雓 度 } \\
\hline & 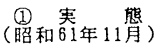 & $\begin{array}{c}\text { (2) 新ダイヤ } \\
\text { ルイクレトかーなし }\end{array}$ & 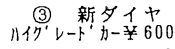 \\
\hline 飯 能 & $33.8 \%$ & $24.6 \%$ & $27.1 \%$ \\
\hline 元加治 & $41.8 \%$ & $30.8 \%$ & $33.9 \%$ \\
\hline 仏子 & $57.4 \%$ & $42.5 \%$ & $46.8 \%$ \\
\hline 入間市 & $78.3 \%$ & $57.6 \%$ & $63.4 \%$ \\
\hline 稲荷山公瞦 & $79.9 \%$ & $58.9 \%$ & $64.6 \%$ \\
\hline 武蔵藤沢 & $109 \%$ & $79.8 \%$ & $87.6 \%$ \\
\hline 荚山ヶ丘 & $148 \%$ & $108 \%$ & $119 \%$ \\
\hline 小手指 & $125 \%$ & $101 \%$ & $108 \%$ \\
\hline 西所沢 & $155 \%$ & $125 \%$ & $133 \%$ \\
\hline 所 沢 & $113 \%$ & $121 \%$ & $123 \%$ \\
\hline 秋 津 & $117 \%$ & $125 \%$ & $127 \%$ \\
\hline 清 瀨 & $142 \%$ & $124 \%$ & $125 \%$ \\
\hline 果久留米 & $165 \%$ & $145 \%$ & $146 \%$ \\
\hline ひばりヶ丘 & $193 \%$ & $169 \%$ & $170 \%$ \\
\hline 保 谷 & $216 \%$ & $157 \%$ & $161 \%$ \\
\hline 大泉学園 & $251 \%$ & $186 \%$ & $187 \%$ \\
\hline 石神井公園 & $241 \%$ & $208 \%$ & $209 \%$ \\
\hline 富土見台 & $250 \%$ & $216 \%$ & $217 \%$ \\
\hline 中村橋 & $256 \%$ & $221 \%$ & $222 \%$ \\
\hline 綀 馬 & $237 \%$ & $234 \%$ & $235 \%$ \\
\hline 婪 台 & $243 \%$ & $239 \%$ & $241 \%$ \\
\hline 江古田 & $248 \%$ & $244 \%$ & $246 \%$ \\
\hline 果昔崎 & $258 \%$ & $254 \%$ & $256 \%$ \\
\hline 椎名町 & $265 \%$ & $261 \%$ & $262 \%$ \\
\hline 袋 & & & \\
\hline
\end{tabular}


表一14 新ダイヤ（ハイグレードカーなし）と現行ダイヤの総所要時間の変化（分/ラッシュ 1 時間 50 分）
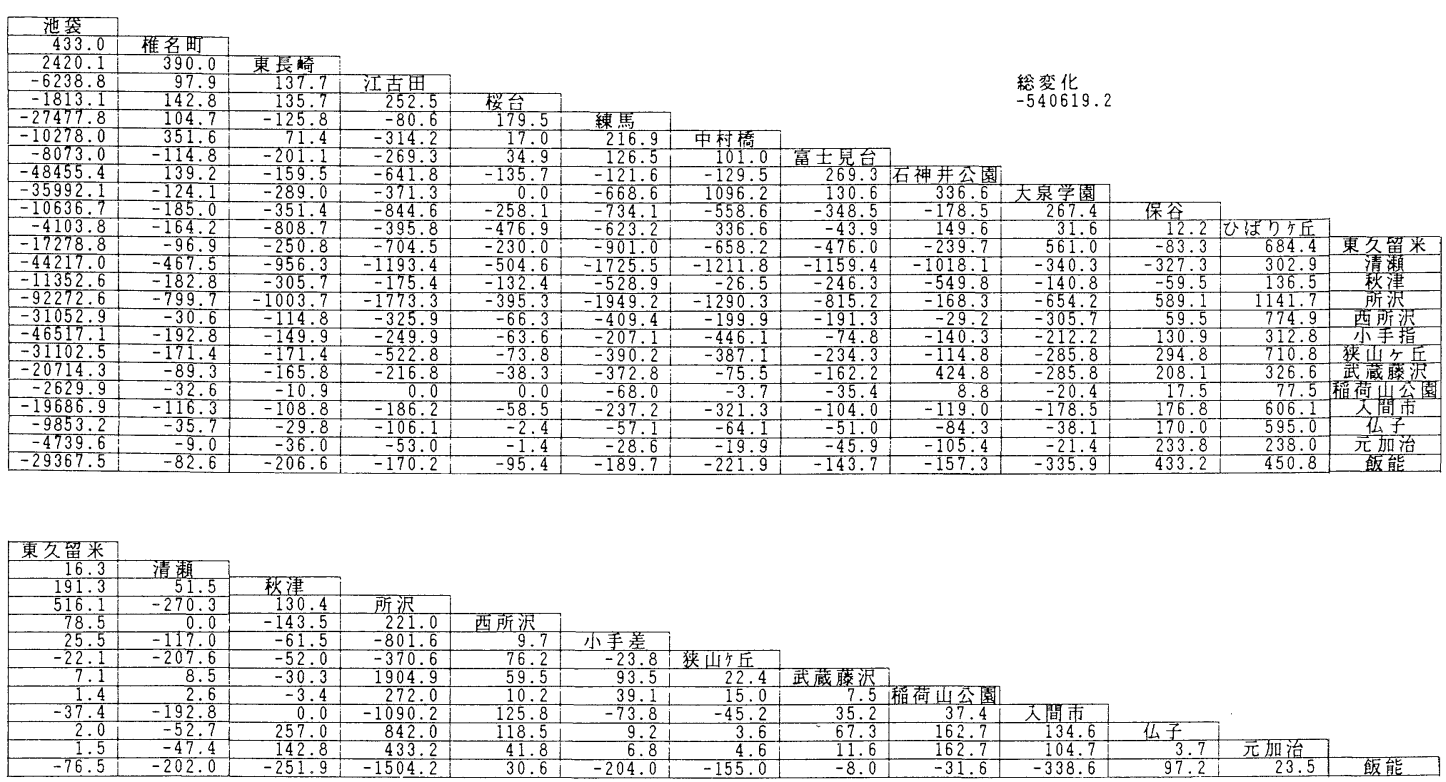

円としてハイグレードカーを導入するケースのほかに， 新ダイヤでハイグレードカーを導入しなかったケースと 現行のケースを加えて比較を行うこととする（表一12 参照).

\section{（6） ODサービスレベルの検討}

対象区間におけるすべての OD に関して, サービス レベルの検討を行った. サービスレベルの評価基準とし てはここでは（2）で挙げた条件の(1)を取り上げた.

混雑度に関しては，データの都合上各駅間における各 列車の平均混雑度により比較した. 結果は表一13のと おりである、利用者が混雑度による不効用を感じ始める のは立席乗車密度 7 人 $/ \mathrm{m}^{2}$ （乗車率 $160 \%$ 相当）程度以 上とされており ${ }^{4)}$, この範囲でみても新ダイヤの平均混 雑度は現行より改善されていることがわかる.

平均総所要時間についても各代替案の差を求めた. 表 一14 はハイグレードカーを導入しなかった場合と現行 とを朝ラッシュ帯（1時間 50 分）について比べたもの であるが，一部の OD を除いては時間節約効果が非常 に大きいことがわかる. ハイグレードカ一ありの場合も ほぼ同様の結果が得られた。

以上から，ハイグレードカーの導入により現在のサー ビスレベルの低下は生じないと判断された.

\section{（7）余剩の計測}

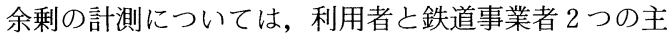
体に分けて，代替案の比較という形で行った.

利用者の余剩の計測については, 基本的には選択行動 を表わす効用関数より効用の変化を求めたうえで, マ ネータームに換算することとし, 効果が時間変化のみの
場合には計算を簡便にするため, 時間変化に時間価値を 掛けることとした。

混雑度に関してはその絶対值と乗車時間に依存すると 考えられるが, 停車駅ごとに変化する混雑度による効用 の積算は現段階では困難である．また表一13からわか るように(2), (3)のケースは(1)よりも改善されており, (2),(3)の差はほとんどないことから，今回は計測の対象 から除外した.代替案(1)から(2)への変化については,サ一 ビスレベルの変化は時間変化だけである.そこで, 平均 総所要時間の差に時間価值を掛けて求めた. (2)から(3)へ の変化については，プロジェクトの有無による便益の差 (UB) が以下の式で近似できる ${ }^{9)}$.

$$
\mathrm{UB}=\frac{1}{2} \sum_{j} \sum_{i}\left(C_{i j}^{A}-C_{i j}^{B}\right)\left(Q_{i j}^{A}+Q_{i j}^{B}\right)
$$

ここに，C：一般化費用

$Q$ : 交通量

$A$ : プロジェクト実施なし

$B$ : プロジェクト実施あり

$i$ : 列車夕イプ $i=1$ : ハイグレードカー $i=2$ : 一般車

$j: \mathrm{OD} ヘ ゚ ア$

ところで $C=\alpha V$ である.ここで $\alpha$ は効用を貨幣単位 にするための変換係数であり,次の式により求められる. $V=-0.045140 \times($ 所要時間 $)-0.041719 \times($ 運転間隔 $)$

$-0.007686 \times$ (料金) +0.667135

×(ハイグレードカーダミー)

$\alpha=-\frac{1}{0.007686}=-130.107$ 
表一15 20 年間に生じる余剩の比較

\begin{tabular}{|r|r|r|r|}
\hline & 3 - - 1 & (2) - (1) & (3)-(2) \\
\hline 利用者余剩 & 762 億円 & 748 億円 & 14 億円 \\
\hline 事業者余剩 & 6 隐円 & -29 億円 & 35 億円 \\
\hline 社会的余剩 & 768 億円 & 719 億円 & 49 虑円 \\
\hline
\end{tabular}

(1) 現行

(2) 新タイヤ(ハイグレードカーなし)

(3) 新タイヤ(ハイグレードカーあり)

ここで $C_{1}^{A}$ はプロジェクトを実施しない場合での八イ グレードカーを選択した一般化費用である. しかし, そ ういうケースは存在しないので, ここでは選択確率 $P_{1}^{A}$ が十分小さくなるようなコストをもって $C_{1}^{A}$ とすること とした，そこで，一般化費用を構成している料金 $F$ と $P$ の関係を検討した結果， $F=1000$ で近似しても差し 支えないと判断したのでその值を用いた．さらに，Q は各 OD 交通量に各列車タイプの選択確率を掛けて求 めた。なお,一本の列車に連結される一般車とハイグレ一 ドカーは, 別個の列車とみなして扱い計算した.

鉄道事業者の余剩については, プロジェクトを通じて 得られる追加収入から追加コストを引くことにより求め た. プロジェクト期間は車両の耐用年数等を考慮し, 20 年とした。なお, コストについてはデータの都合上, こ こでは車両費・人件費・電力費・整備費を対象とし，平 均費用の積み上げ方式とした.

以上により求めた余剩を, 社会的割引率を $5 \%$ とし, 現時点でプロジェクトが実現されたと考え, 今後 20 年 間で比較したのが表一15である。この結果から明らか なようにハイグレードカーの導入は利用者および事業者 に大きな便益をもたらし，社会的にみても有益であるこ とがわかった。

\section{6. 結 論}

本研究では, 都市鉄道の通勤輸送において, 交通の質 についての評価を行い, 乗り換え, 冷房, 着席, エスカ レーター, 混雑度, 待ち時間というサービスに対して利
用者は高い支払意思額を有していることを示した.また， ハイグレードカーの利用についての意識調査を行い, 利 用者の選択行動の特性を明らかにした。ささらに，ハイグ レードカー導入にかかわる純便益の計測を主体別に行 い，適切な料金を設定した場合には，こうしたサービス が独立採算であっても導入可能であることを示すと同時 に，八イグレードカーの導入が社会的にみて大きな効果 をもつことを明らかにした。

なお，本研究を進めるにあたって，西武鉄道株式会社 には意識調査の実施に際し多大な協力をいただき，また 中川 大助手 (現・京都大学) から貴重なコメントをい ただいた。ここに記して感謝の意を表したい。

\section{参 考 文 献}

1）運輸経済研究センター：交通の質 I, II, 1977.

2）安山信雄・藤目節夫 · 大橋健一：公共交通機関のサービ スレベルと利用者満足度に関する基礎的研究, 都市計画 学会学術研究発表会論文集, 第 9 号, pp. 169 174, 1974.

3）家田 仁・松本嘉司：列車選択行動における着席効用度 の定量的評価, 土木学会論文集, 第 365 号, pp. $69 \sim 78$, 1986.

4）美谷邦章・家田 仁・畠中秀人：乗車位置選択モデルを 用いた混雑費用の定量的評価法, 土木計画学研究 - 論文 集, No. 5, pp. 139 146, 1987.

5）阿部 等 - 新谷洋二.太田勝敏 : 大都市放射型鉄道の朝 ピークにおける高サービス提供の可能性, 土木学会第 42 回年次学術講演会, pp. 270 271, 1987.

6）曾根 悟：新しい鉄道システム, オーム社, pp. 65 73, 1987.

7）曽根 悟・松下 泉：地域分離型ダイヤ採用による速達 性と着席率向上を目指した通勤輸送改善案, 電気学会全 国大会, p. 1100, 1986.

8）運輸省：昭和 60 年大都市交通センサス解析調査報告書, p. 115, 1988.

9）土木学会編：海外交通プロジェクトの評価, 鹿島出版会, pp. 98 101, 1986.

10）土木学会 : 非集計行動モデルの理論と実際, 土木計画学 講習会テキスト, 1984.

11）田口玄一: 実験計画法 (上), 丸善, pp. 160 180, 1976.

12）岡野行秀- 山田浩之編：交通経済学講義, 青林書院, 1974.

(1989.2.10 - 受付) 